\title{
Koronavirüs (Covid-19) Salgınının Türkiye'de Genel Ekonomik Faaliyetlere ve Hisse Senedi Borsa Endeksine Etkisi
}

\author{
Ali Cüneyt ÇETIN ${ }^{1}$ \\ ${ }^{1}$ Assoc. Prof. Dr., Burdur Mehmet Akif Ersoy University, Faculty of Economics and Administrative Sciences, \\ Department of Business Administration, Burdur, Turkey
}

Geliş Tarihi/Received: 09.07.2020

Kabul Tarihi/Accepted: 10.09.2020

Araştırma Makalesi/Research Article

\section{ÖZET}

Bu çalışmada 2019 yılı Aralık ayında ortaya çıkan ve 2020 yılı ortalarında etkileri halen devam eden koronavirüs salgınının Türkiye ekonomisi üzerindeki etkisi, hisse senedi borsa endeksi ve genel ekonomik faaliyetlerin düzeyi açısından analiz edilmiştir. Çalışmada hisse senetlerinin fiyat performansı olarak Borsa İstanbul BIST-100 endeksi, genel ekonomik faaliyetlerin düzeyini temsilen de Satın Alma Yöneticileri Endeksi kullanılmıştır. Koronavirüs krizinin etkilerinin hem diğer ülkelerde hem de ülkemizde zirvede olduğu 23 Mart-24 Nisan 2020 tarihleri arasındaki günlük veriler kullanılmıştır. Elde edilen bulgular, incelenen dönemde sosyal mesafe ve sokağa çıkma kısıtlaması uygulamasının genel ekonomik faaliyetlerin seviyesini -0,708 birim düşürdügü ancak hisse senedi fiyatları üzerinde olumsuz bir etkide bulunmadığını göstermiştir. Genel olarak elde edilen sonuçlar, koronavirüs krizinin zirvede olduğu dönemde sokağa çıkma kısıtlaması, yurt içi seyahat kısıtlaması ve yurt dışı seyahat kısıtlaması uygulamaları ile para politikası kararlarının ve kamu harcamaları tutarının genel ekonomik faaliyetlerin seviyesiyle anlamlı bir ilişkide bulunduğunu ve etkilediğini göstermiştir. Söz konusu değişkenlerden yurt dışı seyahat kısıtlamasının BIST-100 hisse senedi borsa endeksinin kapanış fiyatını -0,058, en düşük fiyatını -0,038, para politikası kararlarının hisse senedi borsa endeksinin açılış fiyatını 0,043, en yüksek fiyatını 0,035, en düşük fiyatını 0,024, kapanış fiyatını 0,022 birim etkilediğini göstermiştir. Öte yandan, yurt içi seyahat hareketliliğine getirilen kısıtlamanın, para politikası kararlarının ve kamu harcamalarına ayrılan bütçe tutarının ekonomik faaliyetlerin düzeyi üzerinde olumlu bir etkisi olurken, açıklanan yeni COVID-19 vakaları sayısının hisse senedi endeksinin kapanış, açılış, en yükssek ve en düşük fiyatları ile pozitif yönde ilişkili olduğu görülmüştür. Bulguların sonucunda, para politikası 
Çetin, A. C.

kararlarının kısa dönemde COVID-19 pandemisinin etkilerini hafifletmede kamu harcamaları uygulamasından daha etkili olduğu belirlenmiştir.

Anahtar kelimeler: Covid-19, Koronavirüs, BIST-100, Satın Alma Yöneticileri Endeksi.

\title{
The Impact of the Coronavirus (Covid-19) Pandemic on the General Economic Activities and Stock Market Index in Turkey
}

\begin{abstract}
In this study, coronavirus outbreak occurring in December 2019 and still ongoing its effects in mid-2020, its impact on Turkey's economy was analyzed in terms of the stock market index and the level of general economic activity. Borsa İstanbul BIST-100 index was used as the price performance of stocks while the Purchasing Managers Index was used to represent the level of general economic activities. Daily data between 23 March - 24 April 2020, a period in which the effects of the coronavirus crisis peaked both in other countries and in our country were used. The findings obtained showed that the application of social distance and lockdown restrictions decreased the level of general economic activities by $-0,708$ units in the analyzed period, but had no negative impact on stock prices. Overall results showed that lockdown restriction, domestic travel restriction and international travel restriction practices and monetary policy decisions and public expenditure amount significantly correlated with the level of general economic activities. Among these variables, it has been shown that the foreign travel restriction affected the closing price of the BIST-100 stock exchange index by $-0,058$ and the lowest price by $-0,038$ units, monetary policy decisions affected the opening price of the stock market index by 0.043 , the highest price by 0.035 , the lowest price by 0.024 and the closing price by 0.022 units. On the other hand, the restriction on domestic travel mobility, monetary policy decisions and the amount of budget allocated to public spending have a positive effect on the level of economic activities, while the number of new COVID-19 cases announced has been found to be positively associated with the prices of closing, opening, highest and lowest of the stock index. As a result of the findings, it was determined that monetary policy decisions were more effective than public expenditure practice in alleviating the effects of the COVID-19 pandemic in the short term.
\end{abstract}

Keywords: Covid-19, Coronavirus, BIST-100, Purchasing Managers Index. 


\section{GİRIŞ}

Dünya tarih boyunca birçok salgın hastalıklara tanık olmuştur. Ortaçağ vebası ve türleri ile 1918-1920 y1lları arasında görülen İspanyol gribi bunlardan en fazla etkisini gösteren bulaşıcı hastalıklar olarak karşımıza çıkmıştır. Küresel etkileri olan bulaşıcı hastalıklardan geçtiğimiz 20 yıl içinde 2002-2003 yıllarında şiddetli akut solunum yolu sendromu (SARSCOV), 2004-2006 yıllarında kuş gribi (H5N1) ve 2012 y1lında MERS-COV en yakın zamanda görülen salgın hastalıklar olarak kayıtlara geçmiştir. Dünya, 1 Aralık 2019 tarihinde Çin'in Wuhan kentinde ilk vakanın duyurulmasıyla birlikte koronavirüs ailesinin yeni bir mutasyonu olan COVID-19 adlı bir virüsle karşı karşıya kalmıştır.

Söz konusu salgın hastalıklardan veba ya da diğer adıyla Ortaçağ'ın Kara Ölümü, etkilerini istatistiksel olarak ölçmek zor olsa da tarihin akışını değiştirmiştir. Kara Ölüm, işçi sınıfının rolünü değiştirmiş, sermaye birikimi yapısının ve refah dağılımının yenilenmesine yol açmıştır (Bell ve Levis, 2004). Orta Çağ'da değer kaybına uğrayan emek ve toprak kaynakları, yeni bir kıtanın, Amerika'nın keşfine yol açmıştır. Ayrıca, azalan işgücü arzları, feodalizmden devlet yönetiminin merkezileşmesine geçişe yol açmıştır (Clarck, 2016). Üretimin yapısı, Orta Çağ'da emekten sermayeye, üretici merkezleri ise kırsaldan kente kaymış ve veba salgınının bu değişimler üzerinde önemli etkileri olmuştur (Pamuk, 2007).

İspanyol gribi, 500 Milyondan fazla kişiye bulaşması sonucu 18 ay içinde 50 milyon dolayında insanın ölümüne sebep olarak insanlık tarihinde bilinen en büyük salgınlardan biri (Temel, 2015) olmakla kalmamış aynı zamanda Birinci Dünya Savaşı zamanına denk geldiği için yirminci yüzyılın ekonomisi üzerinde önemli etkileri olmuştur. İspanyol gribi salgınının GSYİH ve tüketim kaybına etkisinin sırasıyla \%6 ve \%8 civarında olduğu ve Birinci Dünya Savaşı, İkinci Dünya Savaşı ve 1929 Dünya Ekonomik Bunalımından sonra gelir ve tüketim üzerinde dördüncü ekonomik şok olduğu görülmüştür. Böylece İspanyol gribi salgını geçmişte toplumu ve ekonomiyi ciddi şekilde etkilemiştir. Ayrıca bu tür salgın felaketlerinin kişi başına \%10 civarında gelir kaybına neden olduğu belirlenmiştir (Barro ve Ursua, 2020).

SARS-COV'in ekonomik etkisi, çıkış kaynağı olan Hong Kongda turizm ve ulaşım gibi talep odaklı sektörlerde önemli ölçüde küçülmeye yol açmış ve kısa vadede tüketim talebinin ve dış ticaretin gerilemesine yol açarak bu sektörlerdeki depresyon işsizlikle sonuçlanmıştır (Siu ve Wong, 2004). Ancak sanayi sektörlerindeki verimlilik etkilenmemiş ve SARS-COV bir talep şoku olarak değerlendirilmiştir. Tayvan ile olan turizm gözden geçirilmiş ve gelen turist sayısının 2002'de 2,98 milyon iken 2003'te 2,24 milyona düştüğü kaydedilmiştir. Tüketim 
harcamaları ve GSYİH da buna göre düşmüş ve turizm ve perakendecilik için işgücü talebinin yılda \%3 ile \%6 arasında azaldığg görülmüştür. Buna göre salgının ekonomik etkisi kısa vadede görülebilmiştir (Yang ve Chen, 2009).

Dünya Sağlık Örgütü, yeni tip koronavirüs (COVID-19) salgınını 2020 yılının 30 Ocak tarihinde uluslararası endişe duyulan bir "halk sağlığı acil durumu" olarak ilan etmiş, 28 Şubat günü küresel risk seviyesini en yükseğe çıkarmış ve 11 Mart tarihi itibariyle de pandemi ilan etmiştir (Fernandes, 2020).

Dünya genelinde açıklanan toplam vaka sayısının 8 Temmuz 2020 tarihi itibariyle 12 milyon kişiye yaklaştığı ve ölü sayısının 547 bine ulaştığı (Worldometer, 2020) bir dönemde, COVID-19 salgının etkisi hayal gücünün de ötesinde sadece insan hayatının kaybı ile sınırlı olmayıp sosyal hayatı ve ekonomi düzenini yerle bir ettiği ve ülkelerin ekonomik istikrarını ve varlığını tehdit ettiği görülmektedir (Bobdey ve Ray, 2020: 9). Vaka sayısı ve ölümler günden güne artıkça hastalığın seyri küresel ekonomi üzerinde hissedilir etkilerini acımasızca göstermeye devam etmektedir.

Türkiye'de ilk vaka 11 Mart 2020 tarihinde görülmüştür. Bu tarihe kadar ülke yönetimi COVID-19 virüsünü ülkemizden uzak tutmayı başarmıştır. Türkiye'de ilk vakanın görülmesinden üç ay öncesinden ülkemizde çeşitli önlemler alınmaya ve düzenlemeler yapılmaya başlanmıştır. İlk vakanın görülmesini takiben alınan erken, etkin ve yerinde tedbirler, önleyici ve duyarlı müdahalelerle salgın kontrol altına alınmış ve vaka sayısı azalma eğilimine girmiştir.

Koronavirüs salgınının ülkemiz ekonomisine verebileceği zararı minimuma indirebilmek amacıyla bazı ekonomik önlemler alınmıştır. Bu doğrultuda ilk önce TCMB harekete geçmiş ve politika faizinde indirime giderek para politikası önlemlerini yürürlüğe koymuştur. TCMB bir hafta vadeli faiz oranını $\% 10.75$ 'ten $\% 9.75$ 'e indirmiş ve bu indirime ek politika kararları da alınmıştır. Bu kararlar şunlardır (Türkiye Cumhuriyeti Merkez Bankası [TCMB], 2020):

- Bankaların gereksinim duydukları tüm likiditenin sağlanması,

- 1 hafta vadeli repo ihalelerine ek olarak gereksinim duyulan günlerde piyasaya 91 gün vadeye kadar repo ihaleleriyle likiditenin sağlanması, 
- Açık Piyasa İşlemleri dahilinde piyasa yapıcı bankalara tanınan likiditeye ilişkin limitlerin arttırılmas1,

- Swap ihalelerinin Euro ve altın karşılığı da düzenlenebilmesi,

- Reel kredi büyüme şartlarını taşıyan bankaların yabancı para zorunlu karşılık oranlarının tüm yükümlülük türlerinde ve tüm vade dilimlerinde 500 baz puan indirilmesi,

• Reel sektöre olan kredi akımını sürdürmek için bankalara hedefli likidite imkanlarının tanınması,

- İhracat ve döviz kazandırıcı hizmetlerin reeskont kredilerine yönelik vade uzatımı imkanının tanınması.

18 Mart 2020 tarihinde “Ekonomik İstikrar Kalkanı” adında bir destek paketi yürürlüğe konulmuştur. Bu paket içerisinde iş dünyasına yönelik yer alan önlemler şu şekilde sıralanabilir (Akbulak, 2020):

- Etkinlik organizasyon, hazır giyim-tekstil, yiyecek-içecek, konaklama, sinema-tiyatro, lojistik-ulaşım, otomotiv, demir-çelik, AVM ve perakende sektörleri için muhtasar ve KDV tevkifatı ile SGK primlerinin Nisan, Mayıs ve Haziran ödemeleri 6'şar ay süreyle ertelenecektir.

- 2020 yılı Kasım ayına kadar konaklama vergisi uygulanmayacaktır.

- Nisan, Mayıs ve Haziran ayları için 6 ay süreyle otel kiralamalarına ilişkin hasılat payı ödemeleri ve irtifak hakkı bedelleri ertelenecektir.

- KOVİD-19 salgınıyla ilgili önlemlerden etkilendiği için nakit akışı bozulan firmaların bankalara olan kredi anapara ve faiz ödemeleri asgari 3 ay ötelenmiş olup, gerektiğinde bunlara ilave finansman desteği sağlanacaktır.

- Kredi Garanti Fonu'na sağlanan destek 25 milyar liradan 50 milyar liraya çıkartılacak, bu kredilerde öncelik gelişmelerden olumsuz etkilendiği için likidite ihtiyacı oluşan ve teminat açı̆̆ı bulunan firmalar ile KOBİ'lere verilecektir.

- İhracattaki geçici yavaşlama sürecinde kapasite kullanım oranlarının korunması amacıyla ihracatçıya stok finansmanı desteği verilecektir.

- Virüsün yayılmasına karşı alınan tedbirlerin etkisiyle Nisan, Mayıs ve Haziran aylarında temerrüde düşen firmaların kredi siciline "mücbir sebep” notu düşülecektir. 
Çetin, A. C.

- Kısa Çalışma Ödeneğinden faydalanmak için gereken süreçler kolaylaştırılacak ve hizlandırılacaktır.

- İstihdamdaki sürekliliği temin etmek amacıyla telafi çalışma süresi 2 aydan 4 aya çıkartılacaktır.

- Asgari ücret desteği devam edecektir.

- 3 ay süreyle KDV oranı iç hava yolu taşımacılığında \%18'den \%1'e indirilecektir.

Ayrıca 16 Nisan 2020 tarihinde TBMM Genel Kurulunda çoğunluğu kamu olmak üzere yaklaşık 10 milyar 140 milyon TL alacağın ertelenmesi kabul edilerek yasalaşmıştır. Salgının olumsuz etkisinden korunmak için sosyal mesafe uygulamasına yönelik alınan tedbirlerden bazıları şunlardır (BBC, 2020):

- 27 Ocak: Dışişleri Bakanlığı tarafından seyahat uyarıları yayınlanmaya başlandı.

- 21 Mart: 65 yaş ve üstü vatandaşlar ile kronik rahatsızlığı olanların sokağa çıkmalarına kısitlama getirildi.

- 21 Mart: Sağlık Bakanlığı Bilim Kurulu kararlarına göre Türkiye'den 46 ülkeye uçuşlar durduruldu.

- 27 Mart: Türk Hava Yolları beş ülke haricinde tüm ülkelerden uçuşları durdurduğunu bildirdi. Yurt içi uçuşların sayısı azaltıldı.

- 28 Mart: Şehirlerarası seyahatler valilik iznine bağlandı.

- 3 Nisan: 20 yaş altında olanlara sokağa çıkma kısıtlaması getirildi. İşçiler sokağa çıkma kısıtlamasından hariç tutuldu.

- 4 Nisan: 30 büyük şehir belirli istisnalar haricinde araç giriş-çıkışına kapatıldı.

• Nisan ayının 11-12, 18-19, 23-26 günleri arası büyük şehir statüsündeki 30 ilde sokağa çıkma yasağı uygulandı.

Bu çalışmada, tüm bu sayılan ekonomik önlemlerle birlikte sosyal mesafe uygulamaları göz önünde bulundurularak, Türkiyede koronavirüs salgının zirvede olduğu Mart ve Nisan ayları ele alınmış, 23 Mart 2020-24 Nisan 2020 tarihleri arası Türkiyede faaliyete geçirilen sosyal mesafe uygulaması (sokağa çıkma kısıtlaması, yurt içi seyahat kısıtlaması, yurt dışı 
seyahat kısıtlaması) ile para politikası kararları ve kamu harcamalarının BIST-100 hisse senedi endeksi ile genel ekonomik faaliyetler üzerindeki etkisi araştırılmıştır.

\section{2. İLGILİ LITERATÜR}

Açıkgöz ve Günay (2020), Covid-19 salgınının küresel ve Türkiye ekonomisi üzerindeki erken etkisini araştırmıştır. Bu bağlamda, hem dünya hem de Türkiye için açıklanan verilere göre pandeminin maliyetlerini değerlendirerek, sektörler boyunca pandeminin kısa ve uzun vadeli küresel ekonomik etkilerinin potansiyel ilk tepkilerini incelemeyi amaçlamıştır. Ayrıca, pandemi sonrası dünya için olası ekonomik ve politik senaryolar ortaya koymaya çalışmıştır. Bu salgının çalışanlar, müşteriler, tedarik zincirleri ve finansal piyasalar üzerinde ciddi olumsuz etkileri olduğu, büyük olasılıkla küresel bir ekonomik durgunluğa neden olabileceği, bununla birlikte, pandeminin sonunun belirsizliği nedeniyle, bu krizin hem uzunluğunun hem de ölçeğinin tahmin edilemeyeceği sonucuna varmıştır.

Albulescu (2020), COVID-19'un uluslararası takibinin başlamasından 40 gün sonra gelen yeni enfeksiyon ve ölüm oranlarına ilişkin resmi açıklamaların, finansal piyasalar oynaklık endeksi (VIX) üzerindeki etkisini araştırmıştır. Çin'de ve Çin dışında bildirilen yeni vakaların finansal oynaklık üzerinde karma bir etkiye sahip olmasına rağmen, ölüm oranının VIX'i olumlu etkilediği ve Çin dışında daha önemli bir etkiyi tetiklediği sonucuna ulaşmıştır. Ayrıca, etkilenen ülke sayısı arttıkça finansal oynaklığın da arttığı sonucuna ulaşmıştır.

Bonaparte (2020), koronavirüsün ekonomik riskini fiyatlandırma üzerine çalışma yapmıştır. Koronavirüsün olası ekonomik riskininin olası sonuçlarını, tüketimin kısmi gecikmesine, tedarik zincirinin bozulmasına ve işgücü üretkenliği şokuna bağlı olarak tüketimdeki durgunluk ölçeğine göre ne kadar değiştiğini fiyatlandırmaktadır. Öncelikle virüsün geçtiği yaşam döngüsünü sunmuş ve yaşam döngüsünün uzunluğunun ekonomik sonuçları belirlediğini tespit etmiştir. Mevcut koronavirüs vakasında bugüne kadar şirketlerin, tüketici harcamalarının azalması veya gecikmesi nedeniyle orijinal 2020 yılı ilk çeyreği kazanç tahminlerini ellerinden kaçıracaklarını belirlemiştir. Gelecekte ise üç ekonomik senaryonun bulunduğunu söylemektedir. Bunlardan ilki, koronavirüsün nisan ortasına kadar belirgin bir düşüş gösterirse, şirketler ilk çeyrekte tüketimdeki gecikmeli artıştan kaynaklanan olağanüstü ikinci çeyrek kazançlarına sahip olacakları, ikincisi, koronavirüsün etkileri Mayıs ayına kadar devam ederse, sınırlı bir iş gücü şoku nedeniyle orta derecede bir durgunluk olacağı, üçüncüsünün ise, tam ölçekli bir durgunluk yaratan genişletilmiş bir salgının bulunduğu şeklindedir. Koronavirüsün yol açtığı GSYİH açıklığını karşılamak için, optimal maliye ve para 


\section{Çetin, A. C.}

politikasının GSYİH açıklığını altyapı projeleri ve işsizlik ödenekleri ile karşılamak için 5 Trilyon \$ kadar bir bütçenin müdahalede kullanılması gerektiğini önermektedir. Ayrıca borsadaki açıklığı gidermek için, Fed'in varlıkları satın alması gerektiğini, bu politikaların ABD ekonomisi ve borsa için yumuşak bir iniş olduğunu vurgulamaktadır.

Ceylan vd. (2020), COVID-19 salgınının potansiyel ekonomik etkilerini analiz etmiştir. Geçmişte yaşanan salgınların çoğunu ve bunların ekonomi ve sosyo-politika üzerindeki etkilerini bilimsel literatürü gözden geçirerek değerlendirmiş ve COVID-19'un potansiyel etkilerini ve bu etkilerin üstesinden gelmenin potansiyel yollarını değerlendirmiştir. Bulaşıcı bir hastalığın olumsuz etkileriyle mücadele etmek için gereken en acil sosyo ekonomik önlemler olarak, işsizliğin gelir etkilerini ve tüm sektörlerin güvenliği ile ilgili olduğunu vurgulamıştır. Çalışmasında, sürekli işsizliği önlemek için hizmet, perakende ve hatta sanayi sektörlerinin desteklenmesi gerektiğini, gelecek için hazırlanacak sağlık hizmetlerinin finansmanının ve yönetsel sürdürülebilirliğinin yeniden düzenlenmesi gerekliliğini önermektedir.

Çakmaklı vd. (2020), COVID-19 krizinin, şimdiye kadar ortaya çıkan en büyük gelişmekte olan piyasa (GP) krizine dönüşebileceğini vurgulamaktadır. GP'lerin, salgınla mücadele için gerekli mali kaynakları bulmaya çalışırken, rekor düzeyde sermaye çıkışlarıyla karşılaştıklarını ve para birimlerinin değerini düşürmeye çalıştıklarını belirtmektedir. Çalışmada büyük bir GP olarak görülen Türkiye üzerine odaklanılmaktadır. Türkiye’nin, düşük döviz rezervleri, yüksek döviz cinsinden borçları ve para politikasının güvenilirliği konusunda sorgulanabilirliği olması ve bunların tamamının GP özelliği olduğu nedeniyle araştırmacılara iyi bir çalışma sahası sunduğu belirtilmektedir. Ekonomi modeli olarak SIR (The Susceptible Infected Recovered-Enfekte Edilmişi Kurtarmaya Duyarlı) adını adlandırdığı basit bir modelleme geliştirmiştir. Değişken olarak telefonla hizmet sunan çalışanlar (teleworkers), fiziksel işe yakınlık ve sokağa çıkma kısıtlaması politikaları ile enfeksiyon oranlarını sentezleyen arz şoklarını almıştır. Kredi kartı ile satın alımlardan kaynaklanan talep şokları belirlenmiştir. Ayrıca, Türkiye'nin ticaret bağlantıları olan küçük bir açık ekonomi olduğu gerçeği çalışmada vurgulanmaktadır. Yaptıkları hesaplamalar, maksimum yaşam sayısını koruyan en düşük ekonomik maliyetin tam olarak uygulanan bir sokağa çıkma kısıtlaması altında elde edilebileceğini göstermektedir. Kısmi sokağa çıkma kısıtlaması, normalleşmeyi daha uzun sürdürdüğü için ekonominin randımanlı çalışmasına geçişi geciktirdiği belirtilmektedir. Ekonomik birimlerin sokağa çıkma kısıtlaması günlerinde finansal destekte bulunulmasının gerekli olduğu vurgulanmakla birlikte, Türkiye'nin politika seçeneklerinin 
düşük finansal destek ve hem dışsal hem de içsel fonlamayı gerektiren sermaye akımlarıyla sınırlı olduğu görülmüştür. Dış fonların uluslararası finans kurumları aracılığıyla temin edilebileceği, yurt içi alanda ise Türkiye Cumhuriyet Merkez Bankasının iyi hedeflenmiş ve şeffaf bir Varlık Satın alma Programı (QE) ile finansman sağlayabileceği, böyle bir politikanın örneği olarak geçmişte başarılı bir şekilde uygulanan, TC Merkez Bankasının, 2001 yılındaki üçlü kriz (bankacılık, egemenlik, denge) sonrasında IMF Stand-By anlaşması kapsamında bildirilen enflasyonla mücadele programı ile devletin borçlanarak fon elde etmesi gösterilmektedir.

Demertzis vd. (2020), COVID-19 salgınını, Avrupa ekonomisi için ele almış ve birtakım öneriler getirmiştir. $\mathrm{Bu}$ öneriler, ulusal sağlık hizmetlerine bol miktarda ulusal fon sağlanması, bireyleri (serbest meslek sahipleri gibi), şirketleri ve en çok etkilenen yerel toplulukları desteklemek için hedeflenmiş önlemler uygulamaya konması veya desteklenmesi ve geniş makroekonomik sigorta sağlanması şeklindedir. Mali ve nakit akışı kısıtlamalarını hafifletmek ve istihdamı korumak için teşvikler sağlamak amacıyla, tüm AB üye ülkelerinin şirketlerin sosyal güvenlik primlerini üç ay için yarıya indirmesini veya bordro vergisini kesmesini tavsiye etmektedir. Bu tür önlemler GSYİH'nın \%2,5'unu destekleyebilir ve artan ulusal açıklar ile finanse edileceğini belirtmektedir. Avrupa Merkez Bankasının, yeterli dolar likiditesini sağlamak için bol miktarda likidite sağlamasını, swap hatlarını artırmasını ve tahvil piyasalarındaki sıkıntıyı önlemek için tahvil alım programının artırılmasını vurgulamaktadır.

Demir vd. (2020), Koronavirüs salgınının durumunu ve bu bağlamda Türkiye ekonomisini incelemişlerdir. Kısa dönemde salgın nedeniyle ekonomik faaliyetlerin \%10 azalacağını varsayarak, 30 günlük bir sürede yaklaşık 31,7 milyar TL tutarında bir Gayri Safi Yurt İçi Hasıla (GSMH) kaybı oluşabileceğini vurgulamışlardır. Kısa dönemli elektrik tüketimindeki azalmaya dayalı bir hesaplamaya göre, GSMH'de \%3,24 oranında bir azalmanın oluşabileceğini, salgının uzun dönemli etkileri göz önüne alındığında, ekonomik kaybın bu kısa dönemli tahminlerden daha fazla olabileceğini belirtmektedirler. Salgının ekonomik büyüme oranında düşüşe, işsizlik ve enflasyon oranında artışa, ödemeler dengesinde ve bütçe dengesinde bozulmaya ve dış finansmanda zorluklarla karşılaşılabileceğine neden olabileceğini tahmin etmektedirler. Uzaktan ve esnek üretim sistemleri gibi önlemlerin, üretimin kesintiye uğramasını engelleyeceğinden ekonomik kayıpların asgariye indirilmesini sağlayacağını, buna ilaveten çeşitli denetim yolları kullanarak üretime geçiş yollarının aranması gerektiğini önermektedirler. İktisadi faaliyetleri tümden sekteye uğratacak uzun dönemli genel karantina şeklindeki yaptırımların maliyetinin çok yüksek olacağından söz etmektedirler. Ekonomiye 


\section{Çetin, A. C.}

gelir transferinde bulunulması, salgının büyüklüğü ve uzun vadeli ekonomik etkileri göz önüne alındığında, garantili borçlar, borç ertelemeleri, vergi ve kredi geri ödemede kolaylıklar ve doğrudan fonlama gibi uygulamaların daha da artırılmasının gerekliliği üzerinde durmaktadirlar.

Demirdöğen ve Yorulmaz (2020), COVID-19 salgınının dünya ekonomilerine etkilerini araştırmış ve Türkiye'nin lehine olabilecek avantajlar da oluşturduğundan bahsetmiştir. Bilhassa, küresel tedarik alt yapısının ve tekelci duruma gelmiş tedarikçinin sorgulanması orta ve uzun dönemde tekstil endüstrisi gibi sahalarda ilk saflarda görünmek isteyen Türkiye namına bir avantaj olduğunu vurgulamıştır. Tedarik şebekesinin çeşitlendirilmesinin zorunluluk haline geldiği bir çevrede üretim farklılaştırılması açısından önemli yol kateden Türkiye ekonomisinin bu lehte durumunu değerlendirmesi gerektiğini, ayrıca söz konusu sürecin Türkiye'nin ihracat, ulaşım, turizm ve reel sektörlerinin küresel alanda yerini sağlamlaştırabilmesi açısından da mühim bir avantaja sahip olduğunu belirtmiştir. Bunu elde edemeyen ülkelerin kaybedeceği, elde edenlerin ise bir basamak yukarıya ulaşacağı bir döneme girildiğini, Türkiye'nin ise bu yeni döneme güçlü bir ülke olarak girebileceğini iddia etmiştir.

Demirhan (2020), COVID-19 salgınının Türkiye'nin BİST 100 endeksine ve CDS primlerine etkisini araştırmıştır. Bu amaçla Türkiye ile karşılaştırmalı olarak, Çin ve 1 Nisan 2020 tarihi itibarıyla en çok vakanın görüldüğü Amerika Birleşik Devletleri’nin ve İtalya'nın hisse senedi piyasa endekslerini ve CDS primlerini incelemiştir. Ayrıca COVID-19 salgınının Türkiye piyasalarında oluşturduğu etkiyi belirlemek için BİST 100 getirilerindeki ve 5 yıl vadeli CDS primlerindeki değişkenliği (volatiliteyi) hesaplamıştır. Salgının volatiliteyi etkilediğini ve hem hisse senedi piyasasının hem de CDS primlerindeki hareketliliğin vaka sayısına verdikleri tepkilerin yatırım kararlarına 1şık tuttuğu sonucuna varmıştır.

Dündar (2020), COVID-19'un tüketici harcamalarına etkisini, 2020 yılı 6 Mart, 13 Mart ve 20 Mart haftalarında yapılan harcamalar ve bu harcamaların haftalık değişimlerini ele alarak incelemiştir. 3 haftada yapılan bu toplam harcama, 2019 yılının 8 Mart, 15 Mart ve 22 Mart haftalarında yapılan toplam harcamayla karşılaştırmıştır.

Fernandes (2020), COVID-19 krizinin endüstriler ve ülkeler üzerindeki ekonomik etkisini incelemiştir. Ekonomik faaliyetin etkileneceği ekonomik kanalları araştırmış, ülkelerde ve endüstrilerde asimetrik sonuçların elde edildiğini belirlemiştir. Ayrıca, farklı senaryolar altında COVID-19'un potansiyel küresel ekonomik maliyetlerinin yaklaşık olarak tahminini yapmaya çalışmıştır. Her ülkenin ekonomik yapısına bağlı olarak, bazılarının diğerlerinden 
daha fazla etkileneceğini, örnek olarak da daha fazla hizmet odaklı ekonomileri olan ülkelerin daha fazla etkileneceğini ve daha fazla iş riski altında olacağını vurgulamaktadır. Bazı olası senaryoları ve bunların ekonomik beklentiler üzerindeki etkisini özetleyerek bulguları uygulanan politika sonuçlarıyla karşılaştırmaktadır.

Gürsoy vd. (2020), Covid-19 koronavirüs salgınıyla finansal göstergeler arasındaki nedensellik ilişkisini ortaya koymayı amaçlamışlardır. Bu bağlamda virüsün ortaya çıktığı ülke olan Çin`in gösterge pay piyasası olan SSEC endeksini bağımlı değişken olarak alırken bağımsız değişken olarak altın, Brent petrol, Bitcoin ve VIX (Volatitity IndeX) endeksi verilerini kullanmışlardır. Ayrıca her bir bağımlı değişken için bağımsız modellerin de kurulduğu çalışmalarında 03.01.2017 ile 10.03.2020 arasındaki günlük veriler (790 gözlem) kullanmışlardır. Sonrasında yine aynı ülke verileri virüsün tespit edildiği 06.12.2019 ile 10.03.2020 dönemlerini kapsayacak şekilde düzenlenmiştir. Toda-Yamamoto (1995) nedensellik testi kullanılarak koronavirüsün finansal göstergeler üzerindeki etkileri araştırılmıştır. Elde edilen analiz sonuçlarına göre, SSEC (Shanghai Composite) endeksi ile Altın ve VIX (korku endeksi) arasında \%5 anlamlılık düzeyinde bir nedensellik ilişsisine rastlanmıştır. SSEC endeksinden altına doğru tek yönlü bir nedensellik olduğu görülürken VIX (korku endeksi) ile iki taraflı bir nedensellik ilişsisinin olduğunu saptamışlardır. Bu sonuçlar çalışmada belirtilen her iki dönem içinde değişim göstermiştir. Fakat SSEC endeksi ve altın fiyatları arasındaki ilişkinin anlamlı olmasının yanında 2019 Aralık sonrasında SSEC endeksinin altın fiyatları üzerinde etkisinin arttığı yönünde bulgulara erişilmiştir.

İban (2020), koronavirüs salgınıyla ilgili olarak, jeo-uzamsal veri biliminin salgının izlenmesi ve yürütülen çalışmaların sonuçlarının gözden geçirilmesi için kullanımını araştırımıştır. Çalışması, pandemi vakaları için gerçek zamanlı jeo-uzamsal veritabanları, tıbbi ihtiyaçların izlenmesi, jeo-uzamsal panolar, pandemi sırasında çevresel değişiklik tespiti ve veri toplama gibi çeşitli tekniklerden oluşmaktadır. Ayrıca, pandemik izolasyon izleme kavramını incelemkte ve önleme ve kurtarma aşamalarındaki etkisini vurgulamaktadır. Sonuç olarak, epidemiyolojik araştırmalarda ve topluluk esnekliğinde jeo-uzamsal veri biliminin kullanımı için bazı öneriler ve geleceğe yönelik perspektifler sunmaktadır.

Nicola vd. (2020), COVID-19'un dünya ekonomisi üzerindeki sosyo ekonomik etkilerini incelemiştir. $\mathrm{Bu}$ krizden sonra ekonomiyi yeniden dengelemek ve yeniden enerjilendirmek için orta ve uzun vadeli planlama yapmak gerektiğini vurgulamaktadır. Sektör planlarına göre sektör ve girişimciliği teşvik eden bir eko sistem de dahil olmak üzere geniş bir 


\section{Çetin, A. C.}

sosyo ekonomik kalkınma planına, aynı zamanda sürdürülebilir iş modellerine sahip olanların yaşayabilmesi için de ihtiyaç duyulduğunu belirtmektedir. Hükümetlerin ve finansal kurumların kriz durumunu sürekli olarak yeniden değerlendirip yeniden değerlendirmeleri ve verdikleri taahhütlerini yerine getirmelerini önermektedir.

Ozili ve Arun (2020), bir sağlık krizinin ekonomik krize nasıl dönüştüğü, koronavirüsün yayılmasının neden küresel ekonomiyi dize getirdiği sorularına cevap aramıştır. Bu soruların cevabının koronavirüsün ekonomik faaliyetlere zarar verdiği iki uygulama içerisinde bulunduğunu söylemektedir. İlki, virüsün yayılmasının, finansal piyasaların, şirket ofislerinin ve işletmelerin kapanmasına yol açan sosyal mesafe uygulamasını getirmesi, diğerinin ise virüsün yayılmasında zirveye ulaştığı oranın ve durumun ne kadar kötüye gidebileceğine dair artan belirsizliğin, tüketiciler, yatırımcılar ve uluslararası ticaret ortakları arasında tüketimi azaltma ve yatırım güvenliğini kaybettirmesi olduğunu vurgulamaktadır. Çalışmada koronavirüsün diğer ülkelere ve pazarlara yayılmaya başladığı 2020 yılı başından Mart ayına kadar olan dönem ele alınmıştır. Dönem içinde uygulanan sokağa çıkma kısıtlayıcı tedbirleri, para politikası önlemlerini, maliye politikası önlemlerini ve halk sağlığı önlemlerini değerlendirirken dünyada oluşan gözlemlerden yararlanmıştır. Sosyal mesafe uygulamalarının ekonomik faaliyetler ve borsa endeksleri üzerindeki etkisini ampirik olarak incelemiştir. Bulgular artan sokağa çıkma kısıtlaması günleri, para politikası kararları ve uluslararası seyahat kısıtlamaları, ekonomik faaliyetlerin seviyesini ve büyük borsa endekslerinin açılış, en düşük ve en yüksek hisse senedi kapanış fiyatını ciddi şekilde etkilediğini ortaya koymuştur. Buna karşılık, yurt içi seyahat üzerine getirilen kısıtlama ve yüksek maliye politikası harcamaları, ekonomik faaliyetlerin düzeyi üzerinde olumlu bir etkiye sahip olmasına rağmen, açıklanan koronavirüs vakalarının artan sayısının ekonomik faaliyetlerin düzeyi üzerinde önemli bir etkisi olmadığı sonucuna ulaşmıştır.

Özatay ve Sak (2020), COVID-19 nedeniyle sokağa çıkma yasağı uygulamasının etkilerini araştırmışlardır. Bu bağlamda sosyal mesafe önleminin hane halkı ve işletmelerde oluşturacağı etkilerin nasıl yönetilebileceğine dair bir görüş ortaya koymuşlardır. Sosyal mesafe uygulamasının başlaması ve süresinin uzaması ile birlikte kamunun yalnızca gelir desteği sağlamak değil, mal ve hizmet üretim sürecini de geçici bir dönem için yeniden yapılandırması gerektiğini vurgulamaktadırlar. Türkiye' de gönüllü ya da zorunlu mesafe koymanın yan etkisini gidermek için kamunun daha etkin davranması gerektiğini önermektedirler. Bu amaçla ilk olarak Hazine ve Maliye Bakanlığının Devlet İç Borçlanma Senedi (DİBS) ihraç etmesini ve DİBS'lerin Merkez Bankası'nca satın alınması diğer bir ifadeyle parasal genişlemenin 
gerekliliğine vurgu yapmaktadırlar. DİBS'lerin bir kısmının bankalarca satın alınması durumunda parasal genişlemenin sınırlandırılabileceğini, ayrıca küresel dayanışma ve iş birliği ile kaynak sorunun hafifletilebileceğini belirtmektedirler.

Peker ve Demirhan (2020), COVID-19'un Borsa İstanbul (BIST)'de işlem gören pay senetlerinin getirileri ve bu getirilerin volatiliteleri üzerindeki etkilerini sektörel olarak incelemişlerdir. COVID-19'un BIST'teki etkilerinin incelenmesinde, 7 Ocak 2020, 11 Mart 2020 ve 21 Mart 2020 olmak üzere 3 kritik tarih göz önüne alınmıştır. COVID-19'un Borsa İstanbul üzerindeki etkilerinin sektörlere göre farklılık gösterdiği, bu farklılıkların, sektörlerin küresel bağlantıları, teknoloji düzeyi, mal ve insan hareketliliğiyle ilişkisine göre değiştiği sonucunu elde etmişlerdir.

Taymaz (2020), Covid-19 önlemlerinin Türkiye ekonomisine etkisini araştırmış ve tavsiyelerde bulunmuştur. Covid-19 tedbirleri kapsamında faaliyeti kısıtlanan sektörlerin kısıtlanmayan sektörlerle üretim ve tüketim düzeyinde etkileşim içerisinde olduğunu belirlemiştir. Üretim düzeyindeki girdi-çıktı ilişkisi nedeniyle, faaliyeti kısıtlanan sektörde üretimin azalmasının girdi üreten ancak faaliyeti kısıtlanmayan sektörlerde de üretimin azalmasına yol açabildiğini vurgulamaktadır. Tüketim düzeyinde faaliyeti kısıtlanan sektörlerdeki işçiler, kendi ürünlerinin yanı sıra faaliyeti kısıtlanmayan sektörlerin de ürünlerini tükettiklerini, bu nedenle faaliyeti kısıtlanan sektörlerde çalışanların gelirindeki düşmenin, faaliyeti kısıtlanmayan sektörlerin ürünlerine olan talebi azalttığını tespit etmiştir.

Tosunoğlu ve Kasal (2020), Covid-19 salgınına yönelik sağlıklı küresel ekonomi için politika uygulamalarını ve Uluslararası Para Fonu (IMF)'nin rolünü araştırmışlardır. Covid-19 ile mücadele adımları olarak hastalığın etkilerinin takip edilmesi, azaltılması ve denetim altına alınması olduğunu vurgulamaktadırlar. Covid-19'un kişilerin sağlıklarıyla birlikte ekonomik refahlarına da ciddi zararlar verdiğini ve ekonomiyi etkilediği birçok kanalın bulunduğunu belirtmektedirler. Sağlık yönetiminin önlemlerinin salgını denetim altına almaya yardımcı olabileceğini, bunun yanı sıra merkez bankalarının, denetleyici ve düzenleyici kurumların da salgının olumsuz ekonomik etkilerini düzeltebilecek tedbirler almaları gerektiğini, bilhassa kamu sağlığ́ ve ekonomik alanda küresel iş birliğinin esas olduğunu vurgulamaktadırlar. IMF'nin bu süreçte salgından etkilenen ülkelere finansal destek dahil çeşitli destekler sağladığını belirtmektedirler.

Uçar vd. (2020), COVID-19 mücadelesinde Türkiye örneğini ele alarak normalleşme sürecini değerlendirmiştir. Çalışmasında salgınla mücadelede tam başarılı olan bir ülkenin 


\section{Çetin, A. C.}

henüz olmadığını, ülkelerin başarısını salgını denetim altına alma çabukluğu ve vefat sayılarının belirlediğini, bu faktörlerin ise sağlık personelinin sayısı, yatak sayısı kapasitesi, ana sağlık hizmetlerinin verilebilmesi, sağlık sigortasının kapsamı gibi etkenlere göre şekillendiğini vurgulamaktadır. Ülkemizdeki sağlık alanında çalışanların fedakârlığının, ülke yönetiminin süratle kriz yönetebilme yeteneğinin, sağlık hizmetlerinin alt yapısının ve halkını mağdur etmemeyi ilke edinen sosyal devlet anlayışının Türkiye'nin güçlü yönleri ve fırsatları olduğunu belirtmektedirler.

\section{METODOLOJI}

\subsection{Veri ve Yöntem}

Türkiye'de COVID-19 pandemi döneminde uygulanan sosyal mesafe politikalarının Türkiye'deki ekonomik faaliyetleri etkileyip etkilemediği incelenmiştir. Toplanan veriler, 23 Mart-24 Nisan 2020 tarihleri arasındaki bir aylık verilerdir. Koronavirüs krizinin 2020 yılı Mart ve Nisan aylarında zirvede olduğu dönemde sosyal mesafe uygulamasının hisse senedi piyasası performansı ile genel ekonomi ve işletme faaliyetleri düzeyi üzerindeki doğrudan ve anlık etkisini daha iyi belirleyebileceği düşünülerek örnekleme döneminin dar tutulmasına karar verilmiştir.

Veriler Borsa İstanbul BIST-100 endeksinin kapanış fiyatı (KF), en düşük fiyat (DF), en yüksek fiyat (YF) ve açılış fiyatı (AF) borsa bilgileri alınmıştır. Hesaplamalarda, hisse senedi fiyatı veri dağılımında gözlenen çarpıklığı azaltmak için her bir fiyat verisinin doğal logaritması alınmıştır.

Ayrıca, Mart ve Nisan aylarına ait Türkiye'nin Satın Alma Yöneticileri Endeksi (PMI) verileri kullanılmıştır. PMI, iktisadi faaliyetin seyrine dair takip edilen önemli göstergelerden biri olarak İstanbul Sanayi Odası ile IHS Markit tarafından düzenlenmektedir. "Türkiye imalat sektöründe faaliyet gösteren yaklaşık 800 şirketten oluşan panelden elde edilen anket verileri kullanılarak oluşturulmaktadır. 10 imalat sektörü için hazırlanan ve üretim, talep, kapasite, fiyatlar ve satın alımları kapsayan endeksler, ilgili sektörlerin ekonomik performansına ilişkin öncü göstergelerdir" (İstanbul Sanayi Odası [ISO], 2020). PMI, bu yönüyle imalat ve hizmet sektörlerindeki ekonomik eğilimlerin yönünü göstermektedir. PMI bu çalışmada genel ekonominin ve ticari faaliyetlerin düzeyini (ED) temsil etmektedir.

Açıklayıcı değişkenler olarak, sosyal mesafe politikalarını belirlemek için üiç değisşken kullanılmıştır. Bunlar, sokağa çıkma kısıtlaması uygulanan günlerin sayısı (SY), yurt içi 
seyahat kısıtlaması uygulanan günlerin sayısı (YISS) ve yurt dışı seyahat kısıtlaması uygulanan günlerin sayısı (YDS)'dir. Ayrıca, ilgili dönemde para politikası kararlarından biri olarak belirlenen, borç sözleşmesinde iyileştirmeye yönelik uygulama (PP), kamu harcamalarının tutarı (KH) ve COVID-19 yeni vakalarının sayısı (CS) değişken olarak kullanılmıştır. KH ve CS verilerinin dağılımında gözlenen çarpıklığı azaltmak için KH ve CS değişkenlerinin doğal logaritması alınmıştır.

YİS, YDS, PP, KH ve CS değişkenleri için veriler Oxford COVID-19 Kamu Müdahale İzleyicisi veri tabanı (Oxford COVID-19 Government Response Tracker [OxCGRT], 2020)'den alınmıştır. OxCGRT, Oxford Üniversitesi'nde geliştirilen bir sistemle salgın sırasında hükümetlerin politika tepkisini izleyen bir veri tabanı olarak "ülkelerin aldıkları tedbirler, hayata geçme tarihlerine ve düzeylerine göre kaydedilmektedir. Böylece her ülkeye özgü "sıkılık endeksi” (stringency index) hesaplanmaktadır. Bu puan, ülkelerin COVID-19 önlemlerinin ne kadar sıkı olduğunu göstermekte ve ülkelerin karşılaştırılabilir olmasını sağlamaktadır” (Uçar vd., 2020: 2).

Sokağa çıkma kısıtlaması uygulanan gün değişkeni (SY)'de ayarlama yapılarak Tablo 1'deki gibi puanlanmıştır. 
Çetin, A. C.

Tablo 1. Sokağa çıkma kısıtlaması uygulanan günlerin puanlaması

\begin{tabular}{|c|c|c|c|c|c|}
\hline & & 65 Yaş ve Üzeri (Puan) & 0-15 Yaş Arası (Puan) & 15-20 Yaş Arası (Puan) & Toplam Puan \\
\hline 23.03 .2020 & Pazartesi & 1 & 5 & 3 & 9 \\
\hline 24.03 .2020 & Sal1 & 2 & 6 & 4 & 12 \\
\hline 25.03 .2020 & Çarşamba & 3 & 0 & 5 & 8 \\
\hline 26.03 .2020 & Perşembe & 4 & 1 & 6 & 11 \\
\hline 27.03 .2020 & Cuma & 5 & 2 & 0 & 7 \\
\hline 28.03 .2020 & Cumartesi & 6 & 3 & 1 & 10 \\
\hline 29.03 .2020 & Pazar & 0 & 4 & 2 & 6 \\
\hline 30.03 .2020 & Pazartesi & 1 & 5 & 3 & 9 \\
\hline 31.03 .2020 & Sal1 & 2 & 6 & 4 & 12 \\
\hline 01.04 .2020 & Çarşamba & 3 & 0 & 5 & 8 \\
\hline 02.04 .2020 & Perşembe & 4 & 1 & 6 & 11 \\
\hline 03.04 .2020 & Cuma & 5 & 2 & 0 & 7 \\
\hline 04.04 .2020 & Cumartesi & 6 & 3 & 1 & 10 \\
\hline 05.04 .2020 & Pazar & 0 & 4 & 2 & 6 \\
\hline 06.04 .2020 & Pazartesi & 1 & 5 & 3 & 9 \\
\hline 07.04 .2020 & Sal1 & 2 & 6 & 4 & 12 \\
\hline 08.04 .2020 & Çarşamba & 3 & 0 & 5 & 8 \\
\hline 09.04 .2020 & Perşembe & 4 & 1 & 6 & 11 \\
\hline 10.04 .2020 & Cuma & 5 & 2 & 0 & 7 \\
\hline 11.04 .2020 & Cumartesi & 6 & 3 & 1 & 10 \\
\hline 12.04 .2020 & Pazar & 0 & 4 & 2 & 6 \\
\hline 13.04 .2020 & Pazartesi & 1 & 5 & 3 & 9 \\
\hline 14.04 .2020 & Sal1 & 2 & 6 & 4 & 12 \\
\hline 15.04 .2020 & Çarşamba & 3 & 0 & 5 & 8 \\
\hline 16.04 .2020 & Perşembe & 4 & 1 & 6 & 11 \\
\hline 17.04 .2020 & Cuma & 5 & 2 & 0 & 7 \\
\hline 18.04 .2020 & Cumartesi & 6 & 3 & 1 & 10 \\
\hline 19.04 .2020 & Pazar & 0 & 4 & 2 & 6 \\
\hline 20.04 .2020 & Pazartesi & 1 & 5 & 3 & 9 \\
\hline 21.04 .2020 & Sal1 & 2 & 6 & 4 & 12 \\
\hline 22.04 .2020 & Çarşamba & 3 & 0 & 5 & 8 \\
\hline 23.04 .2020 & Perşembe & 4 & 1 & 6 & 11 \\
\hline 24.04 .2020 & Cuma & 5 & 2 & 0 & 7 \\
\hline
\end{tabular}

Tablo 1'de sokağa çıkma kısıtlamasının ilk gününe '1', ikinci gününe '2', üçüncü gününe '3' ve diğer günler aynı şekilde artarak giderken, serbest kalınan günler diğer bir ifadeyle her yaş kategorisi için sokağa çıkma kısıtlaması olmayan günler '0' olarak puanlanmıştır. Böylece verilerden panel veri elde edilmiştir.

\subsection{Model}

Model, en küçük kareler yöntemi kullanılarak hesaplanan çok değişkenli bir regresyon modelidir. Model aşağıda gösterilmektedir. 


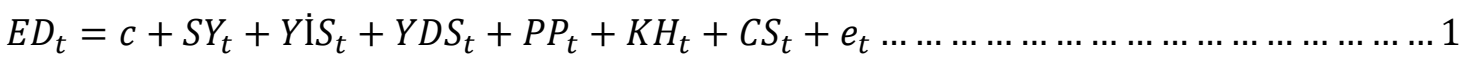

$H S_{t}=c+S Y_{t}+Y \dot{I} S_{t}+Y D S_{t}+P P_{t}+K H_{t}+C S_{t}+e_{t} \ldots \ldots \ldots \ldots \ldots \ldots \ldots \ldots \ldots \ldots \ldots \ldots \ldots 2$

$E D=$ genel ekonomik faaliyetlerin düzeyi (PMI)

$H S=$ hisse senedi borsa endeksi değişkenlerinin log vektörü: $\mathrm{KF}, \Delta \mathrm{KF}$, DF ve $\mathrm{YF}$

$t=$ haftanın iş günü

Tanımlayıcı istatistikler, korelasyon katsayıları ve regresyon analizi sonuçları Tablo 2, Tablo 3 ve Tablo 4'de gösterilmektedir.

Tablo 2. Tanımlayıc1 istatistikler

\begin{tabular}{|c|c|c|c|c|c|c|c|c|c|c|c|}
\hline & KF & YF & $\mathrm{DF}$ & $\mathrm{AF}$ & ED & SY & YİS & YDS & PP & $\mathrm{KH}$ & $\mathrm{CS}$ \\
\hline Ortalama & 11,4 & 11,5 & 11,4 & 11,4 & 15,05 & 9,1 & 19,9 & 3,9 & 0,4 & 30,30 & 7,9 \\
\hline Ortanca & 11,4 & 11,5 & 11,4 & 11,4 & 15,00 & 9,0 & 21,0 & 4,0 & 0,0 & 37,50 & 8,1 \\
\hline En büyük & 11,5 & 11,5 & 11,5 & 11,5 & 31,00 & 12,0 & 38,0 & 4,0 & 1,0 & 62,50 & 8,5 \\
\hline En küçük & 11,4 & 11,4 & 11,3 & 11,3 & 0,20 & 6,0 & 0,0 & 3,0 & 0,0 & 0,00 & 5,7 \\
\hline $\begin{array}{l}\text { Standart } \\
\text { Sapma }\end{array}$ & 0,04 & 0,04 & 0,04 & 0,04 & 9,59 & 2,0 & 11,6 & 0,3 & 0,5 & 29,32 & 0,7 \\
\hline Gözlem & 24 & 24 & 24 & 24 & 33 & 33 & 33 & 33 & 33 & 33 & 24 \\
\hline $\begin{array}{l}\mathrm{KF}=\mathrm{BIST} \\
\mathrm{AF}=\mathrm{BIST} \\
\mathrm{DF}=\mathrm{BIST} \\
\mathrm{YF}=\mathrm{BIST} \\
\mathrm{ED}=\text { gen } \\
\mathrm{SY}=\text { soka } \\
\mathrm{YIS}=\text { yur } \\
\mathrm{YDS}=\text { yu } \\
\mathrm{PP}=\text { para } \\
\mathrm{KH}=\text { kam } \\
\mathrm{CS}=\mathrm{CO} \\
* * * 0.01, * \\
\mathrm{~T}-\text { istatistig }\end{array}$ & $\begin{array}{l}00 \text { en } \\
00 \text { en } \\
00 \text { en } \\
00 \text { en } \\
\text { ekono } \\
\text { çı1km } \\
\text { ci seya } \\
\text { diş1 se } \\
\text { litika } \\
\text { harcar } \\
\text { D-19y } \\
.05 \text { * } \\
\text { leğerle }\end{array}$ & $\begin{array}{l}\text { Sinin } \\
\text { sinin } \\
\text { sinin } \\
\text { sinin } \\
\text { faaliye } \\
\text { sitlan } \\
\text { kisitl } \\
\text { lat k1s } \\
\text { ararlat } \\
\text { arının } \\
\text { vaka } \\
0 \text { anlan } \\
\text { arantez }\end{array}$ & 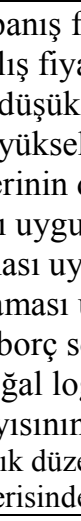 & $\begin{array}{l}\text { at1 } \\
\text { yat1 } \\
\text { eyi } \\
\text { an gür } \\
\text { anan } \\
\text { ulana } \\
\text { esmes } \\
\text { itmas } \\
\text { ğal lo } \\
\text { i göste } \\
\text { sterilm }\end{array}$ & $\begin{array}{l}\text { ayıs1 } \\
\text { n says1 } \\
\text { zün say } \\
\text { de iyile } \\
\text { ritmas } \\
\text { eektedir } \\
\text { tedir }\end{array}$ & irme) & & & & & \\
\hline
\end{tabular}

Tablo 3. Pearson korelasyon

\begin{tabular}{|l|l|l|l|l|l|l|l|l|l|l|l|}
\hline & KF & YF & DF & AF & ED & SY & YİS & YDS & PP & KH & CS \\
\hline KF & 1 & & & & & & & & & & \\
\hline YF &, $833^{* *}$ & 1 & & & & & & & & & \\
\hline DF &, $813^{* *}$ &, $813^{* *}$ & 1 & & & & & & & & \\
\hline AF &, $875^{* *}$ &, $875^{* *}$ &, $938^{* *}$ & 1 & & & & & & & \\
\hline ED &, $864^{* *}$ &, $856^{* *}$ &, $860^{* *}$ &, $860^{* *}$ & 1 & & & & & & \\
\hline SY &,- 134 &, 045 &,- 119 &,- 052 &,- 114 & 1 & & & & & \\
\hline YİS &, $808^{* *}$ &, $829^{* *}$ &, $800^{* *}$ &, $819^{* *}$ &, $969^{* *}$ &, 035 & 1 & & & & \\
\hline YDS &, $447^{*}$ &, $447^{*}$ &, $496^{*}$ &, $522^{* *}$ &, $629^{* *}$ &,- 160 &, $717^{* *}$ & 1 & & & \\
\hline PP &, $775^{* *}$ &, $775^{* *}$ &, $859^{* *}$ &, $791^{* *}$ &, $851^{* *}$ &,- 046 &, $781^{* *}$ &, 346 & 1 & & \\
\hline KH &, $926^{* *}$ &, $909^{* *}$ &, $791^{* *}$ &, $839^{* *}$ &, $917^{* *}$ &,- 081 &, $866^{* *}$ &, $470^{*}$ &, $747^{* *}$ & 1 & \\
\hline CS &, $638^{* *}$ &, $638^{* *}$ &, $671^{* *}$ &, $707^{* *}$ &, $753^{* *}$ &,- 069 &, $811^{* *}$ &, $889^{* *}$ &, $478^{*}$ &, $658^{* *}$ & 1 \\
\hline
\end{tabular}


Çetin, A. C.

Tablo 4. Sosyal mesafe uygulamasının hisse senedi borsa endeksine ve genel ekonomik faaliyetlere etkisi

\begin{tabular}{|c|c|c|c|c|c|}
\hline & (1) & (2) & (3) & (4) & (5) \\
\hline & $\mathrm{KF}$ & $\mathrm{AF}$ & DF & YF & $\mathrm{ED}$ \\
\hline SY & $\begin{array}{r}-0,0017 \\
(-0,94)\end{array}$ & $\begin{array}{c}-0,0009 \\
(-0,42)\end{array}$ & $\begin{array}{c}-0,0012 \\
(-0,63)\end{array}$ & $\begin{array}{c}-0,0007 \\
(-0,40)\end{array}$ & $\begin{array}{c}-0,7082 * * * \\
(-6,35)\end{array}$ \\
\hline YİS & $\begin{array}{c}0,0016^{*} \\
(1,74)\end{array}$ & $\begin{array}{c}-0,0012 \\
(-1,10)\end{array}$ & $\begin{array}{l}0,0007 \\
(0,75)\end{array}$ & $\begin{array}{l}-0,0009 \\
(-1,05)\end{array}$ & $\begin{array}{c}0,6709 * * * \\
(10,55)\end{array}$ \\
\hline YDS & $\begin{array}{c}-0,0583 * * \\
(-2,69)\end{array}$ & $\begin{array}{c}-0,0156 \\
(-0,62) \\
\end{array}$ & $\begin{array}{c}-0,0389 * \\
(-1,72) \\
\end{array}$ & $\begin{array}{r}-0,0305 \\
(-1,49) \\
\end{array}$ & $\begin{array}{c}-3,8733 * * * \\
(-2,77)\end{array}$ \\
\hline PP & $\begin{array}{c}0,0224 * \\
(2,04)\end{array}$ & $\begin{array}{c}0,0430 * * * \\
(3,40)\end{array}$ & $\begin{array}{c}0,0246 * * \\
(2,15)\end{array}$ & $\begin{array}{c}0,0359 * * * \\
(3,46)\end{array}$ & $\begin{array}{c}2,4622 * * * \\
(3,35)\end{array}$ \\
\hline $\mathrm{KH}$ & $\begin{array}{c}0,0064 * \\
(1,74)\end{array}$ & $\begin{array}{c}0,0123 * * * \\
(2,89)\end{array}$ & $\begin{array}{c}0,0091 * * \\
(2,37) \\
\end{array}$ & $\begin{array}{c}0,0123 * * * \\
(3,54) \\
\end{array}$ & $\begin{array}{c}0,6610 * * * \\
(2,97)\end{array}$ \\
\hline CS & $\begin{array}{c}0,0248 * * \\
(2,51)\end{array}$ & $\begin{array}{c}0,0347 \text { *** } \\
(3,04)\end{array}$ & $\begin{array}{c}0,0324 * * * \\
(3,14)\end{array}$ & $\begin{array}{c}0,0316^{* * * *} \\
(3,38)\end{array}$ & $\begin{array}{c}0,7141 \\
(1,11) \\
\end{array}$ \\
\hline R2 & 0,93 & 0,93 & 0,94 & 0,94 & 0,99 \\
\hline Ayarlı R2 & 0,91 & 0,90 & 0,92 & 0,91 & 0,99 \\
\hline Gözlem & 24 & 24 & 24 & 24 & 33 \\
\hline $\begin{array}{l}\mathrm{KF}=\mathrm{BIST} \\
\mathrm{AF}=\mathrm{BIST} \\
\mathrm{DF}=\mathrm{BIST} \\
\mathrm{YF}=\mathrm{BIST} \\
\mathrm{ED}=\text { gene } \\
\mathrm{SY}=\text { soka } \\
\mathrm{YIS}=\text { yurt } \\
\mathrm{YDS}=\text { yur } \\
\mathrm{PP}=\text { para } \\
\mathrm{KH}=\mathrm{kam} \\
\mathrm{CS}=\mathrm{COV} \\
* * * 0.01, * * \\
\mathrm{~T}-\text { istatistiği }\end{array}$ & $\begin{array}{l}\text { eksinin kapa } \\
\text { eksinin aç1l } \\
\text { eksinin en d } \\
\text { eksinin en y } \\
\text { ii faaliyetler } \\
\text { kısitlaması } \\
\text { at kısıtlama } \\
\text { ahat kisıtlan } \\
\text { kararları (b } \\
\text { lalarının doğ } \\
\text { eni vaka sayı } \\
.10 \text { anlamll11k } \\
\text { parantez içer }\end{array}$ & $\begin{array}{l}\text { atı } \\
1 \\
\text { iyatı } \\
\text { fiyatı } \\
\text { izeyi } \\
\text { unan gün say } \\
\text { ulanan gün } \\
\text { ygulanan gü } \\
\text { zleşmesinde } \\
\text { aritması } \\
\text { loğal logarit } \\
\text { ini göstermel } \\
\text { gösterilmekte }\end{array}$ & $\begin{array}{l}\text { S1 } \\
\text { tirme) }\end{array}$ & & \\
\hline
\end{tabular}

Tablo 4'de görüldüğü üzere SY değişkeni sadece sütun 5'te anlamlıdır. Bu nedenle sokağa çıkma kısıtlaması uygulanan günlerin hisse senetlerinin kapanış, açılış, en düşük ve en yüksek fiyatlarını etkilemediği, katsayının negatif olması nedeniyle genel ekonomik faaliyetlerin düzeyini (ED) önemli ölçüde etkilediği görülmektedir. YİS değişkeni 1 ve 5 numaralı sütunlarda anlamlı ve genel ekonomik faaliyetlerin düzeyi ile önemli derecede ilişkilidir. YİS değişkeni katsayısının pozitif olması nedeniyle, yurt içi seyahat kısıtlamasında yapılan 1 birim değişmeyle birlikte ekonomik faaliyetlerin düzeyinde aynı yönde 0.67 birim değişmenin görüldüğü sonucuna varılabilir. YDS değişkeni 1, 3 ve 5 numaralı sütunlarda anlamlıdır ve hisse senedinin kapanış, en düşük fiyat ve ED değişkeni ile negatif ilişkilidir. Bu, koronavirüs pandemisi sırasında uygulanan yurt dışı seyahat kısıtlamasının, hisse senedi fiyatlarından ziyade ekonomik faaliyetlerin üzerinde daha önemli bir etkiye sahip olduğunu göstermektedir. PP değişkeni, tüm sütunlarda anlamlı ve pozitif değerdedir. Bu, para politikası kararlarının ekonomik faaliyetlerin düzeyi ve kapanış, açılış, en düşük ve en yüksek hisse senedi fiyatları üzerinde olumlu bir ilişkiye sahip olduğunu göstermektedir. KH değişkeni tüm 
sütunlarda pozitif ve katsayısı anlamlıdır. Bu sonuç kamu harcamaları büyüklüğünün hisse senedi fiyatları ve ekonomik faaliyetlerin düzeyi üzerinde olumlu bir etkisi olduğunu göstermektedir. CS değişkeni 5 numaralı sütunda hariç diğer tüm sütunlarda anlamlı ve pozitif değerdedir. Bu da açıklanan COVID-19 yeni vaka sayılarının ekonomik faaliyetlerin düzeyi üzerinde önemli bir etkisi olmadığını göstermektedir.

\section{SONUÇ}

Birçok ülke koronavirüs salgınının yayılmasını önlemek için çeşitli müdahale yöntemlerinde bulunmaktadır. Ülkemizin aldığı hızlı politika kararları bu müdahalelerin en etkili ve diğer ülkelere örnek olabilecek seviyede uygulamalarını içermektedir. Birçok ülkede sosyal mesafe uygulamaları ve sokağa çıkma kısıtlamalarının getirilmesi ile birlikte bu tür sosyal politikaların ekonomide durgunluğu tetikleyebileceği yönünde tartışmalar olmuştur. $\mathrm{Bu}$ çalışmada 2019 yılı Aralık ayında ortaya çıkan ve 2020 yılı ortalarında etkileri halen devam eden koronavirüs salgınının Türkiye ekonomisi üzerindeki etkisi hisse senedi borsa endeksi ve genel ekonomik faaliyetlerin düzeyi açısından analiz edilmiştir. Koronavirüs krizinin etkilerinin hem diğer ülkelerde hem de ülkemizde zirvede olduğu bir dönem olan 23 Mart - 24 Nisan 2020 tarihleri arasındaki bir aylık verilerin analiz edilmesinden elde edilen bulgular, incelenen dönemde sosyal mesafe ve sokağa çıkma kısıtlaması uygulamasının genel ekonomik faaliyetlerin seviyesini -0,708 birim düşürdügü ancak hisse senedi fiyatları üzerinde olumsuz bir etkide bulunmadığını göstermiştir.

Genel olarak elde edilen sonuçlar, koronavirüs krizinin zirvede olduğu dönemde sokağa çıkma kısıtlaması, yurt içi seyahat kısıtlaması ve yurt dışı seyahat kısıtlaması uygulamaları ile para politikası kararlarının ve kamu harcamaları tutarının genel ekonomik faaliyetlerin seviyesiyle anlamlı bir ilişkide bulunduğunu ve etkilediğini göstermiştir. Söz konusu değişkenlerden yurt dışı seyahat kısıtlamasının BIST-100 hisse senedi borsa endeksinin kapanış fiyatını -0,058, en düşük fiyatını -0,038, para politikası kararlarının hisse senedi borsa endeksinin açılış fiyatını 0,043 , en yüksek fiyatını 0,035 , en düşük fiyatını 0,024, kapanış fiyatını 0,022 birim etkilediğini göstermiştir. Öte yandan, yurt içi seyahat hareketliliğine getirilen kısıtlamanın, para politikası kararlarının ve kamu harcamalarına ayrılan bütçe tutarının ekonomik faaliyetlerin düzeyi (ED) üzerinde olumlu bir etkisi olurken, açıklanan yeni COVID19 vakaları sayısının hisse senedi endeksinin kapanış, açılış, en yüksek ve en düşük fiyatları ile pozitif yönde ilişkili olduğu görülmüştür. Bulguların sonucunda, para politikası kararlarının 
k1sa dönemde COVID-19 pandemisinin etkilerini hafifletmede kamu harcamaları uygulamasından daha etkili olduğu belirlenmiştir.

\section{REFERENCES / KAYNAKLAR}

Açıkgöz, Ö. \& Günay, A. (2020). The early impact of the covid-19 pandemic on the global and Turkish economy. Turkish Journal of Medical Sciences, 50( ), 520-526.

Akbulak, Y. (2020). Covid-19 salgının ekonomik etkileri için ne yaptık? Erişim tarihi: 15.06.2020, https://www.dunya.com/kose-yazisi/covid-19-salginininekonomik-etkileri-icin-ne-yaptik/470268

Albulescu, C. (2020). Coronavirus and financial volatility: 40 days of fasting and fear. Erişim tarihi: 08.03.2020, https://arxiv.org/ftp/arxiv/papers/2003/2003.04005.pdf

Barro, R. J., Ursua, J. F. \& Weng, J. (2020). The coronavirus and the great influenza epidemic lessons from the "Spanish Flu" for the Coronavirus's Potential Effects on Mortality and Economic Activity. CESifo Working Papers, ISSN 2364-1428, Paper No: 8166, 1-26.

BBC (2020). Adım adım Türkiye'nin covid-19'la mücadelesi. (3 Haziran 2020). Erişim tarihi: 08.07.2020, https://www.bbc.com/turkce/haberler-turkiye-52899914

Bell, C. \& Lewis, M. (2004). The economic implications of epidemics old and new. World Econ, 5(4), 137-174.

Bonaparte, Y. (2020). Pricing the economic risk of coronavirus: a delay in consumption or a recession? Erişim tarihi: 05.03.2020, http://dx.doi.org/10.2139/ssrn.3549597

Ceylan, R. F., Ozkan, B. \& Mulazimogullari, E. (2020). Historical evidence for economic effects of covid-19. The European journal of health economics: HEPAC: Health economics in prevention and care, 1-7. Advance online publication. Erişim tarihi: 04.07.2020, https://doi.org/10.1007/s10198-020-01206-8

Clark, G. (2016). Microbes and markets: Was the black death an economic revolution? JODE - Journal of Demographic Economics, Cambridge University Press, 82(2), 139-165. Erişim tarihi: 20.08.2020, http://dx.doi.org/10.1017/dem.2016.6

Çakmaklı, C., Demiralp, S., Özcan, S. K., Yeşiltaş, S. \& Yıldırım, M. A. (2020). Covid-19 and emerging markets: The case of Turkey. Koç University-TUSIAD Economic Research Forum Working Papers 2011, https://eaf.ku.edu.tr/wp-content/uploads/2020/05/erf_wp_2011.pdf

Demertzis, M., Sapir, A., Tagliapietra, S. \& Wolf, G. B. (2020). An effective economic response to the Coronavirus in Europe. Policy Contributions 35323, Bruegel. Erişim tarihi: 14.06.2020, https://www.bruegel.org/wpcontent/uploads/2020/03/PC-06-2020-130320.pdf

Demir, İ., Khan, M. M., Yorulmaz, R. \& Kaptan, S. (2020). Kovid-19 (Koronavirüs) salgınının ekonomik etkileri. Ankara Yıldırım Beyazıt Üniversitesi Uluslararası İlişkiler ve Stratejik Araşıımalar (ULISA) Enstitüsü Politika Notu, Sayl: 1, https://www.researchgate.net/profile/Ibrahim_Demir6/publication/340619067_Kovid19_Koronavirus_Salgininin_Seyri_ve_Turkiye_Ekonomisi/links/5e9699b0299bf130799ad155/

Demirdöğen, O. \& Yorulmaz, R. (2020). Kovid-19 salgınının dünya ekonomilerine etkileri. Ortadoğu

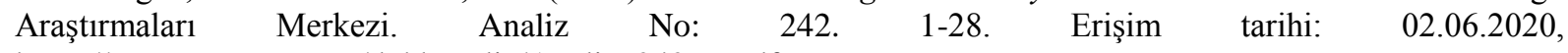
https://www.orsam.org.tr/d_hbanaliz/Analiz_242_tr.pdf

Demirhan, E. (2020). Covid-19 Küresel salginınin Türkiye CDS primlerine ve BiST 100 endeksine etkisi. Türkiye Ekonomi Politikaları Araştırma Vakfı (TEPAV), Değerlendirme Notu, Erişim tarihi: 12.06.2020, https://www.tepav.org.tr/upload/files/15857330326.COVID_19_Kuresel_Salgininin_Turkiye_CDS_Primlerine_ ve_BIST_100_Endeksine_Etkisi.pdf 
Dündar, M. (2020). Covid-19’un tüketici harcamalarına etkisi. Türkiye Ekonomi Politikaları Araştırma Vakfı (TEPAV), Değerlendirme Notu, $\quad$ Erişim tarihi: http://www.tepav.org.tr/upload/mce/2020/notlar/covid19un_tuketici_harcamalarina_etkisi.pdf

Fernandes, N. (2020). Economic effects of coronavirus outbreak (COVID-19) on the world economy. (Mart 22, 2020). Erişim tarihi: 18.06.2020, http://dx.doi.org/10.2139/ssrn.3557504

Gürsoy, S., Tunçel, M. B. \& Sayar, B. (2020). Koronavirüsün (Covid-19) finansal göstergeler üzerine etkileri, Ekonomi Maliye İsletme Dergisi, 3(1), 20-32. Doi: 10.46737/emid.730941

İban, M. C. (2020). Geospatial data science response to COVID-19 crisis and pandemic isolation tracking. Turkish Journal of Geosciences. 1(1) 1-7.

İstanbul Sanayi Odası (ISO). Türkiye sektörel pmi anketi. Erişim tarihi: 19.06.2020, http://www.iso.org.tr/file/PMI-sektorel-mart2020_TR-9852.pdf

Nicola, M., Alsafi, Z., Sohrabi, C., Kerwan, A. \& Al-Jabir. A. (2020). The socio-economic implications of the coronavirus pandemic (Covid-19): A review. International Journal of Surgery, 78, 185-193. https://doi.org/10.1016/j.ijsu.2020.04.018

Oxford COVID-19 Government Response Tracker (OxCGRT). Coronavirus government response tracker. Erişim tarihi: 21.06.2020, https://www.bsg.ox.ac.uk/research/research-projects/coronavirus-government-responsetracker

Ozili, P. \& Arun, T. (2020). Spillover of covid-19: Impact on the global economy. SSRN Electronic Journal, Erişim tarihi: 22.05.2020, Doi: 10.2139/ssrn.3562570, https://www.researchgate.net/profile/ Peterson_Ozili/publication/340236487_Spillover_of_COVID-19_impact_on_the_Global_Economy/links/ 5ea31041299bf11256096e6c/Spillover-of-COVID-19-impact-on-the-Global-Economy.pdf

Özatay, F. \& Sak, G. (2020). Covid-19 nedeniyle sokağa çıkma yasağı uygulanırsa. Türkiye Ekonomi Politikaları Araştırma Vakfı (TEPAV), Değerlendirme Notu, Erişim tarihi: 12.06.2020, http://www.tepav.org.tr/upload/mce/2020/notlar/covid19_nedeniyle_sokaga_cikma_yasagi_uygulanirsa.pdf

Pamuk, S. (2007). The Black death and the origins of the great divergence across Europe. European Review of Economic History, 11(3), 289-317.

Peker, Y. \& Demirhan, E. (2020). Covid-19 küresel salgınının borsa İstanbul'daki sektörel etkileri. Türkiye Ekonomi Politikaları Araştırma Vakfı (TEPAV), Değerlendirme Notu, Erişim tarihi: 08.06.2020, http://www.tepav.org.tr/upload/mce/2020/notlar/covid19_kuresel_salgininin_borsa_istanbuldaki_sektorel_etkiler i.pdf

Siu, A. \& Wong, V.C.R. (2004). Economic impact of SARS: The case of Hong Kong. Asian Econ. Papers MIT Pres, 3(1), 62-83.

Taymaz, E. (2020). Covid-19 tedbirlerinin Türkiye ekonomisine etkisi ve çözüm önerileri. SARKAÇ. Erişim tarihi: 01.06.2020, https://sarkac.org/2020/04/covid19-tedbirlerinin-turkiye-ekonomisine-etkisi-cozum-onerileri/

Temel, M. K. (2015). Gelmiş geçmiş en büyük katil: 1918 "İspanyol" gribi. İstanbul: BETİM Kitaplı̆̆ı. ISBN: 978-605-86957-2-6.

Tosunoğlu, Ş. \& Kasal, S. (2020). Yeni koronavirüs (covid-19) salgını ve sağlıklı küresel ekonomi için politika uygulamaları: IMF'nin rolü. Anadolu Üniversitesi İktisat Fakültesi Dergisi. 2(1), 35-49.

Türkiye Cumhuriyeti Merkez Bankası (TCMB). Türkiye Cumhuriyeti merkez bankası para politikası kurulu kararl. Erişim tarihi: 19.06.2020, https://www.tcmb.gov.tr/wps/wcm/connect/ tr/tcmb+tr/main+menu/ duyurular/basin/2020/duy2020-15

Uçar, A., Çavdar, S. \& Arslan Ş. (11.05.2020). Kovid-19 mücadelesinde Türkiye örneği ve normalleşme süreci. Erişim tarihi: 16.06.2020, https://www.aa.com.tr/tr/analiz/kovid-19-mucadelesinde-turkiye-ornegi-venormallesme-sureci/1836789\#! 
Çetin, A. C.

Yang, H. Y. \& Chen, K. H. (2009). A general equilibrium analysis of the economic impact of a tourism crisis: A case study of the SARS epidemic in Taiwan. J. Policy Res. Tour. Leis. Events, 1(1), 37-60. https://doi.org/10.1080/19407960902738313

Worldometer. Covid-19 coronavirus pandemic. $\quad$ Erişim tarihi: 08.07.2020, https://www.worldometers.info/coronavirus/ 